\title{
Pengaruh Lingkungan Kerja Terhadap Kinerja Pegawai Di Masa Pandemi Covid 19 (Studi Kasus Pada Pegawai Kelurahan Salembaran Jaya)
}

\author{
${ }^{1}$ Po. Abas Sunarya, ${ }^{2}$ Padeli, ${ }^{3}$ Siti Dian Cahya Dwi Oktavionita \\ ${ }^{1}$ Program Studi Manajemen Retail Universitas Raharja, ${ }^{2}$ Program Studi \\ Komputerisasi Akutansi Universitas Raharja, \\ ${ }^{3}$ Program Studi Sistem Informasi Universitas Raharja \\ E-mail : ${ }^{1}$ abas@ raharja.info, ${ }^{2}$ padeli@ raharja.info, ${ }^{3}$ siti.dian@ raharja.info
}

\begin{abstract}
Abstrak
Pandemi covid-19 sangat berpengaruh terhadap lingkungan kerja sehingga kinerja pegawai instansi pemerintahan desa yang menjadikan kurang optimal dalam bekerja. Kinerja pegawai dalam pelayanan masyarakat di Kelurahan Salembaran kurang maksimal karena pelayanan masyarakat oleh pegawai Kelurahan Salembaran Jaya terkendala karena faktor penyesuaian dengan protokol covid-19 sehingga terjadi perubahan pelayanan masyarakat yang menjadikan kinerja pegawai kurang maksimal dan optimal dalam bekerja. Kegiatan-kegiatan para pegawai juga dibatasi karena harus mengikuti protokol covid-19 yang sudah diterapkan untuk menghindari penyebaran virus covid-19. Dalam hal ini kebersihan ruangan menjadi faktor yang harus diperhatikan agar seluruh pegawai benar-benar merasa nyaman dan aman dengan selalu mematuhi protokol yang ada sehingga dapat meningkatkan kinerja para pegawai yang menjadikan tujuan dari instansi pemerintahan desa dapat tercapai secara maksimal. Penelitian ini mempunyai tujuan yaitu untuk menunjukkan adanya pengaruh lingkungan kerja terhadap kinerja pegawai pada instansi pemerintahan desa yaitu Kelurahan Salembaran Jaya. Kegiatan analisis menggunakan metode kuantitatif dengan melakukan beberapa pengujian. Hasil akhir penelitian ini memberitahukan adanya pengaruh signifikan antara lingkungan kerja dengan kinerja pegawai.
\end{abstract}

Kata Kunci : Pandemi Covid-19, Lingkungan Kerja, Kinerja Pegawai, Kelurahan Salembaran Jaya

\begin{abstract}
The COVID-19 pandemic greatly affects the work environment so that the performance of village government agency employees is less than optimal at work. Employee performance in community service in community services in the Salembaran Village is less than optimal because community service by Salembaran Jaya Village employees is constrained due to adjustment factors to the Covid-19 protocol, resulting in changes in community services that make employee performance less than optimal and optimal at work. The activities of employees are also limited because they have to follow the covid-19 protocol that is applied to avoid the spread of covid-19. In this case the cleanliness of the room is a factor that must be considered so that all employees really feel comfortable and safe by always complying with existing protocols so that they can improve employee performance so that goals of village government agencies can be achieved optimally. This study has a purpose, namely to show the effect of the work esnvironment on employee performance in village government agencies, namely Salembaran Jaya Village. Analytical activities use quantitative methods by conducting several tests. The final result this study informs there is a significant effect in the work environment and employee performance.
\end{abstract}

Keywords: Covid-19 Pandemic, Work Environment, Employee Performance, Salembaran Jaya Village 


\subsection{Latar belakang}

\section{Pendahuluan}

Pada masa pandemi covid-19 ini membuat semua sarana mati atau ditutup sementara. Pandemi covid-19 tidak hanya terjadi pada Negara Indonesia melainkan terjadi pada NegaraNegara lainnya. Di Indonesia sudah melakukan berbagai macam cara agar covid-19 ini tidak semakin memanas mulai dari diterapkannya protokol pencegahan penularan covid-19, social distancing yaitu tindakan untuk tidak diperkenankan berjabat tangan dan menjaga jarak setidaknya 1 meter, serta diterapkannya pembatasan sosial berkala besar (PSBB) yang dilakukan setiap provinsi, kota hingga daerah-daerah terpencil. Namun, itu semua tidak menjadikan covid-19 menghilang begitu saja dikarenakan belum sepenuhnya ada kesadaran diri untuk melakukan pencegahan penularan covid-19. Pondasi dalam mencegah penularan covid-19 adalah dengan mematuhi protokol yang telah diterapkan yaitu dengan menggunakan masker ketika sedang beraktivitas diluar ataupun tidak, mencuci tangan pakai sabun dan air mengalir, menghindari kerumunan dimanapun dan kapanpun itu, menjaga kesehatan diri sendiri, tidak melakukan perjalanan ke manapun apabila tidak benar-benar penting. Sampai detik inipun covid-19 masih ada dan semakin menambah korban yang terkena covid-19. Hal tersebut berdampak pada lingkungan kerja sekaligus kinerja para pegawai. Segala aktivitas sangat berubah drastis semenjak adanya pandemi ini dikarenakan seluruh aktivitas dilakukan secara online. Hal yang paling penting dalam suatu pemerintahan desa yaitu kinerja pegawai. Menurut Nabawi (2019:171) kinerja pegawai merupakan salah satu faktor penentu keberhasilan instansi atau organisasi dalam mencapai tujuannya. Jika kinerja para pegawai baik maka tujuan pemerintahan desa akan mudah tercapai, maka dari itu Kelurahan Salembaran Jaya harus bisa mengetahui faktor-faktor yang kiranya dapat menurunkan kinerja pegawai dalam bekerja, dikarenakan pegawai adalah hal penting dalam meningkatkan sebuah intansi pemerintahan desa. Kinerja pegawai merupakan sebuah investasi utama dari suatu instansi pemerintahan desa yang dapat mencapai tujuan dari instansi pemerintahan desa tersebut. Kinerja pegawai adalah sebuah cerminan untuk dapat mengetahui apakah suatu pemerintahan desa telah berjalan dengan baik atau tidak. Apabila pemerintahan desa sudah berjalan dengan baik maka dapat menghasilkan kinerja pegawai yang baik pula yang nantinya akan mempengaruhi dalam melakukan pelayanan kepada masyarakat. Apabila pemerintahan desa tidak berjalan dengan baik maka dapat memberikan dampak negatif pada kinerja pegawai dalam melakukan pelayanan kepada masyarakat.

Kelurahan Salembaran Jaya mempunyai visi yaitu pendeskripsiann mengenai masa yang akan datang yang dijadikan cerminan mengenai kondisi di Kelurahan Salembaran Jaya. Dengan demikian visi dari Kelurahan Salembaran Jaya adalah terwujudnya kehidupan masyarakat kelurahan Salembaran Jaya yang maju, cerdas, beriman dan mandiri. Sedangkan misi Kelurahan Salembaran Jaya adalah pencerminan dari tercapainya visi Kelurahan Salembaran Jaya yaitu dengan memfasilitasi peningkatan SDM (Sumber Daya Manusia), pemeliharaan ketentraman serta ketertiban masyarakat, memujudkan tertib administrasi kependudukan dan catatan sipil, mewujudkan prasarana dan sarana wilayah yang memadai. Adapula Nilai dari Kelurahan Salembaran Jaya yang menjadi kriteria untuk perbaikan serta kebenaran yang diyakini dan ditetapkan sehingga menjadi nilai ataupun norma yang yang diyakini dalam kehidupan seluruh aparat Pemerintahan Kelurahan Salembaran Jaya dalam melakukan tugasnya masing-masing dalam rangka untuk mencapai visi dan misi Kelurahan Salembaran Jaya, nilai Kelurahan Salembaran Jaya yaitu disiplin dalam melakukan pekerjaan serta dalam kehidupan sehari-hari, efisien dan fektif dalam bekerja, transparan dalam melakukan pekerjaan agar tidak adanya penyalahgunaan jabatan, komitmen dalam melakukan pekerjaan.

Dalam menciptakan visi, misi dan nilai tersebut Kelurahan Salembaran Jaya sesuai dengan tugas pokoknya yaitu penyelenggaraan terhadap pelayanan masyarakat, pengelolaan fasilitas umum sebagai pengembangan ekonomi dan usaha kecil maka tujuan dari pemerintahan Kelurahan Salembaran Jaya adalah Meningkatkan pelayanan yang optimal disegala bidang 
dalam rangka terciptanya pembangunan yang berkelanjutan. Hal tersebut yang menjadikan kinerja para pegawai penting dalam melakukan pelayanan masyarakat apalagi pada saat ini semua aktivitas selalu berhubungan dengan online dikarenakan tidak bisa bertatap secara langsung seperti biasanya. Pada kondisi seperti ini siapapun itu dianjurkan untuk mematuhi protokol yang sudah diterapkan oleh Pemerintah Pusat sebagai langkah pencegahan penularan covid-19 serta perlu adanya kesadaran diri masing-masing untuk menjaga kesehatan tubuh dan tentunya tetap melakukan pencegahan penularan covid-19 dengan mematuhi protokol yang sudah diterapkan. Aktivitas yang biasanya dilakukan secara langsung sekarang ini semua itu berubah menjadi daring mulai dari aktivitas di sekolah, kantor, intansi pemerintahan desa serta aktivitas lainnya. Dengan menjaga jarak satu sama lain sudah termasuk ke dalam hal pencegahan penularan covid-19, maka dari itu Kelurahan Salembaran Jaya melakukan pengubahan pada tempat duduk para pegawai yaitu dengan memberi jarak antar pegawai dan memberi jarak terhadap masyarakat yang mempunyai kepentingan di kelurahan Salembaran Jaya.

Saat ini kebersihan ruangan juga menjadi faktor yang harus diperhatikan agar seluruh pegawai benar-benar merasa nyaman dan tentunya dengan selalu mematuhi protokol yang ada yaitu dengan mengenakan masker saat sedang bekerja maupun tidak, mencuci tangan pakai sabun dan air mengalir sebelum dan setelah beraktivitas serta menerapkan social distancing yaitu tindakan untuk tidak diperkenankan berjabat tangan dan menjaga jarak setidaknya 1 meter. Menurut Susanto (2020:160) lingkungan kerja merupakan salah satu faktor yang dapat mempengaruhi kinerja karyawan. Kondisi lingkungan pekerjaan yang aman, nyaman serta menyenangkan akan berpengaruh kepada para pegawai agar bekerja lebih maksimal. Keberhasilan peningkatan kinerja pegawai menuntut instansi pemerintahan desa mengetahui lingkungan kerja yang baik untuk peningkatan kinerja semua pegawai. Jika instansi pemerintahan desa mempunyai lingkungan kerja yang baik, aman, nyaman serta menyenangkan akan menghasilkan kinerja yang baik pula. Salah satu lingkungan kerja yang aman, nyaman dan menyenangkan, dari segi fisik seperti : suhu ruangan, fasilitas kerja, luas ruang kerja, jarak tempat duduk antar pegawai dan masyarakat yang berkepentingan di Kelurahan serta adanya penyemprotan disinfektan untuk setiap ruangan sebagai salah satu pencegahan covid-19. Sedangkan dari segi non fisik dapat berupa : hubungan kerja antara atasan dengan bawahan serta sesama pegawai maupun pihak-pihak yang mempunyai kepentingan di Kelurahan Salembaran Jaya.

Kebersihan ruangan pada Kelurahan Salembaran Jaya sangat diperhatikan, mulai dari kebersihan ruangan pimpinan Kelurahan, ruangan para pegawai, toilet sampai lingkungan sekitar Kelurahan Salembaran Jaya agar para pegawai merasa nyaman dengan lingkungan yang bersih dan dapat berpengaruh positif pada kinerja dalam bekerja. Serta selalu menyediakan halhal yang termasuk dalam pencegahan penularan covid-19 seperti handsinitizer, tempat cuci tangan, bilik penyemprotan disinfektan, pengecekan suhu untuk para pegawai dan pihak-pihak yang berkepentingan di Kelurahan Salembaran Jaya, dan selalu rajin melakukan penyemprotan disinfektan untuk setiap ruangan serta sudut-sudut ruangan setiap harinya. Dan bukan hanya itu saja tetapi diperlukan kesadaran masing-masing pegawai untuk melakukan pencegahan penularan covid-19 untuk diri sendiri. Pihak-pihak yang berkepentingan di kelurahan Salembaran Jaya juga selalu diingatkan untuk tetap memakai masker dan mematuhi protokol yang telah diterapkan. Dengan cara seperti itu dapat mencegah penularan covid-19 sehingga dapat membawa pengaruh yang baik pula untuk kinerja para pegawai Kelurahan Salembaran Jaya.

Pada latar belakang diatas menguraikan bahwa yang menjadi pengaruh dari lingkungen kerja di indtansi pemerintahan desa saat ini adalah adanya pandemi covid-19 yang belum tahu kapan akan selesai. Virus yang semakin hari semakin memakan banyak korban yang tertular menjadikan semua aktivitas berubah yang akhirnya berdampak pada kinerja para pegawai di 
instansi pemerintahan desa maupun instansi lainnya. Saat ini pegawai Kelurahan Salembaran Jaya sudah melakukan pencegahan penularan covid-19 dengan protokol yang telah diterapkan di Kelurahan Salembaran Jaya serta sudah adanya kesadaran diri untuk melakukan pencegahan penularan untuk diri sendiri karena untuk melakukan pencegahan penularan harus dilakukan mulai dari diri sendiri terlebih dahulu. Melihat dari latar belakang tersebut, maka peneliti melakukan sebuah penelitian yang berjudul "Pengaruh Lingkungan Kerja Terhadap Kinerja Pegawai Di Masa Pandemi Covid 19 (Studi Kasus Kelurahan Salembaran Jaya)".

\subsection{Rumusan Masalah}

Rumusan masalah biasnya berisi tentang pertanyaan mengapa dan bagaimana mengenai topik penelitian yang diambil serta masalah-masalah seperti apa yang hendak dipecahkan ataupun diketahui dalam penelitian. Rumusan pada penelitian ini yaitu untuk merumuskan permasalahan yang terjadi pada tempat penelitian. Perumusan masalah penelitian ini yaitu untuk menunjukkan terdapatnya pengaruh antara lingkungan kerja dengan kinerja pegawai di masa pandemi covid-19 (studi kasus Kelurahan Salembaran Jaya).

\subsection{Batasan Masalah}

Setiap penelitian tentunya memiliki batasannya masing-masing. Dalam hal ini yang menjadi batasan masalah yaitu mengenai pengaruh lingkungan kerja terhadap kinerja pegawai di masa pandemi covid-19. Jadi, ruang lingkup penelitian hanya difokuskan pada pegawai yang terdaftar pada Kelurahan Salembaran Jaya dan kegiatan yang dapat mempengaruhi kinerja pegawai.

\subsection{Tujuan Penelitian}

Pada penelitian ini menguraikan secara tegas dan jelas mengenai tujuan dilaksanakannya penelitian pada sebuah instansi pemerintahan desa. Adanya tujuan penelitian yaitu untuk menghitung seberapa besar pengaruh lingkungan kerja terhadap kinerja pegawai pada saat ini, mengetahui apakah perlu adanya pembaharuan dalam semua hal yang berkaitan dengan meningktanya ataupun menurunnya kinerja pegawai.

\subsection{Manfaat Penelitian}

Setiap penelitian pastinya memiliki manfaatnya masing-masing. Manfaat merupakan hal yang berarti ataupun berguna untuk objek dalam sebuah penelitian. Manfaat penelitian ini yaitu untuk mengetahui seberapa berpengaruhnya lingkungan kerja terhadap kinerja pegawai pada Kelurahan Salembaran Jaya. Penelitian ini juga dilakukan sebagai bukti bahwa adanya perubahan atau pengaruh lingkungan kerja terhada kinerja pegawai apalagi di masa pandemic covid-19 sekarang ini.

\section{Metode Penelitian}

Metode penelitian menggunakan metode kuantitatif untuk menunjukkan terdapatnya pengaruh antara lingkungan kerja dengan kinerja para pegawai pada masa pandemi covid-19. Berikut penjelasan mengenai metode yang digunakan, diantaranya :

\subsection{Populasi dan Sampel}

\subsubsection{Populasi}

Populasi diambil dari seluruh pegawai Kelurahan Salembaran Jaya berjumlah 15 orang. Jumlah pegawai pada Kelurahan Salembaran Jaya terbilang sangat sedikit, sama sekali tidak mencapai 50 orang ataupun 100 orang. Pegawai kelurahan Salembaran Jaya berjumlah 15 orang sudah termasuk jumlah pegawai secara keseluruhan yang terdiri dari pimpinan Kelurahan yaitu lurah, sekretaris Kelurahan, bendahara Kelurahan, staf pemberdayaan masyarakat, staf ketentraman dan ketertiban.

\subsubsection{Sampel}

Sampel yang yang diambil tentunya berasal dari jumlah populasi yang ada yaitu jumlah pegawai Kelurahan Salembaran Jaya secara keseluruhan. Objek penelitian yang dijadikan sebagai sampel penelitian sangat sedikit maka peneliti mengambil semua sampel yaitu sebanyak 
15 sampel yang akan dijadikan sampel dalam perhitungan dengan sebuah pengujian-pengujian yang dapat menunjukkan adanya pengaruh antar variabel yang dijelaskan melalui sebuah perhitungan.

\subsection{Operasional variabel}

Penelitian ini menjelaskan definisi operasional variabel untuk menjauhi kesalahankesalahan dalam mengartikan setiap variabel-variabel yang akan dianalisis.

1. Variabel X, pada penelitian ini adalah "Lingkungan Kerja".

2. Variabel Y, pada penelitian ini adalah "Kinerja Pegawai".

Tabel 1. Operasional Variabel

\begin{tabular}{|c|c|c|c|c|c|}
\hline No. & Variabel & Dimensi & Indikator & $\begin{array}{c}\text { Item } \\
\text { Pertanyaan }\end{array}$ & $\begin{array}{c}\text { Skala } \\
\text { Pengukuran }\end{array}$ \\
\hline 1. & $\begin{array}{l}\text { Variabel } \\
\text { Lingkungan } \\
\text { Kerja (X) }\end{array}$ & $\begin{array}{l}\text { 1. Faktor fisik } \\
\text { 2. Faktor non } \\
\text { fisik }\end{array}$ & $\begin{array}{l}\text { 1. Peralatan kerja } \\
\text { 2. Suhu tempat kerja } \\
\text { 3. Fasilitas pencegahan covid-19 (masker, tempat } \\
\text { cuci tangan) } \\
\text { 4. Luas ruangan kerja } \\
\text { 5. Jarak antar pegawai } \\
\text { 6. Hubungan dengan atasan } \\
\text { 7. Hubungan dengan sesama pegawai } \\
\text { 8. Hubungan dengan masyarakat umum }\end{array}$ & $\begin{array}{c}1-2 \\
3 \\
4-5 \\
6 \\
7 \\
8 \\
10 \\
9\end{array}$ & Skala Ordinal \\
\hline 2. & $\begin{array}{l}\text { Variabel } \\
\text { Kinerja } \\
\text { Pegawai (Y) }\end{array}$ & 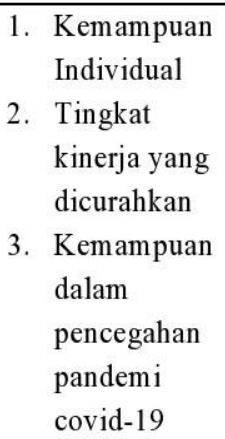 & $\begin{array}{l}\text { 1. Inisiatif kerja yang baik dalam bekerja } \\
\text { 2. Memiliki inisiatif untuk menjaga jarak serta } \\
\text { melakukan pencegahan pandemi covid-19 } \\
\text { 3. Memiliki tanggungjawab dalam bekerja } \\
\text { 4. memiliki tingkat kehadiran yang tinggi } \\
\text { 5. Mempunyai keterampilan dan pengetahuan dalam } \\
\text { menyelesaikan pekerjaan }\end{array}$ & $\begin{array}{c}1-2 \\
9-10 \\
5-6 \\
7-8 \\
3-4\end{array}$ & Skala Ordinal \\
\hline
\end{tabular}

Pada tabel 1, menunjukkan bahwa peneliti menggunakan dua variabel yaitu $\mathrm{X}$ dan $\mathrm{Y}$ sebagai pengartian dari variabel yang ada agar tidak terjadi kesalahan dalam mengartikan setiap variabel. Setiap variabel memiliki dimensi masing-masing yaitu sebagai pembeda antar variabel. Setiap variabel memiliki dimensi yang dijadikan acuan dalam memberi pertanyaan yaitu terdapat pada item pertanyaan diatas mulai dari dimesi yang dilihat dari faktor fisik dan non fisik, sampai dimensi yang dilihat dari kemampuan individual, tingkat kinerja serta kemampuan dalam melakukan pencegahan penularan covid-19.

Tabel operasional variabel menunjukkan adanya indikator yaitu sebagai item -item pertanyaan yang akan dijadikan sebagai acuan untuk perhitungan pengujian tahap selanjutnya. Indikator ini salah satu hal penting untuk menunjukkan adanya pengaruh antar variabel atau tidak. Pada setiap indikator pula memiliki jumlah item-item pertanyaan, satu indikator tidak mesti memiliki satu pertanyaan 
melainkan bisa lebih dari satu pertanyaan semua itu tergantung pada berapa item yang ingin ditanyakan pada setiap indikator yang ada. Operasional variabel ini menggunakan skala pengukuran yaitu dengan skala pengukuran ordinal karena untuk membedakan setiap data yang ada melalui penilaian-penilaian tertentu seperti pengujian-pengujian yang bersangkutan dengan metode yang digunakan.

\subsection{Teknik Analisis Data}

Kegiatan analisis menggunakan metode kuantitatif dengan beberapa pengujian yaitu :

1. Pengujian Validitas

2. Pengujian Reliabilitas

3. Analisis Regresi Sederhana

4. Analisis Korelasi (R)

5. Pengujian Hipotesis (Uji t)

Pada penelitian ini menggunakan pengujian-pengujian yang telah disebutkan diatas karena untuk mengetahui setiap perhitungan dari pengujian serta nilai pengaruh antar variabel untuk mengetahui hasil akhir dari penelitian ini. Dari pengujian tersebut akan diketahui bahwa adanya keterkaitan antar variabel serta dapat dikatakan bahwa adanya pengaruh signifikan antar variabel. Pengujian tersebut biasa digunakan untuk mengetahui nilai antar variabel yang ingin dicari tahu yang kemudian disimpulkan sesuai dengan hasil yang telah ditunjukkan dari pengujian tersebut.

\subsection{Pengujian Validitas}

\section{Hasil Penelitian dan Pembahasan}

Pengujian digunakan sebagai pengenalan tingkat keakuratan setiap indikator yang dijadikan uji ukur variabel. Pengujian ini memakai korelasi t hitung yaitu hasil $t$ hitung dibedakan antara $t$ tabel dengan $\mathrm{df}=\mathrm{n}-2$ nilai sig 5\% atau 0.05 . Apabila $\mathrm{t}$ tabel $<\mathrm{t}$ hitung dikatakan valid sedangkan $\mathrm{t}$ hitung $<$ $\mathrm{t}$ tabel dikatakan tidak valid. Dibawah ini merupakan hasil pengujian validitas yaitu :

Tabel 2. Uji Validitas

\begin{tabular}{|c|c|c|c|c|c|c|}
\hline Variabel & Item & Korelasi & $\begin{array}{l}\text { Nilai t } \\
\text { hitung }\end{array}$ & $\begin{array}{c}\text { Nilai t } \\
\text { tabel }\end{array}$ & $\begin{array}{c}\text { Taraf } \\
\text { Sig }(a=0,05)\end{array}$ & Keterangan \\
\hline $\mathrm{X}$ & $\begin{array}{l}\text { X.1 } \\
\text { X.2 } \\
\text { X.3 } \\
\text { X.4 } \\
\text { X.5 } \\
\text { X.6 } \\
\text { X.7 } \\
\text { X. } 8 \\
\text { X.9 } \\
\text { X. } 10\end{array}$ & $\begin{array}{l}0.99 \\
0.99 \\
0.86 \\
0.99 \\
0.99 \\
0.74 \\
0.99 \\
0.76 \\
0.95 \\
0.86\end{array}$ & $\begin{array}{c}21.11 \\
21.11 \\
6.02 \\
21.11 \\
21.11 \\
3.97 \\
21.11 \\
4.27 \\
10.57 \\
6.02\end{array}$ & $\begin{array}{l}1.77 \\
1.77 \\
1.77 \\
1.77 \\
1.77 \\
1.77 \\
1.77 \\
1.77 \\
1.77 \\
1.77\end{array}$ & $\begin{array}{l}0.05 \\
0.05 \\
0.05 \\
0.05 \\
0.05 \\
0.05 \\
0.05 \\
0.05 \\
0.05 \\
0.05\end{array}$ & $\begin{array}{l}\text { Valid } \\
\text { Valid } \\
\text { Valid } \\
\text { Valid } \\
\text { Valid } \\
\text { Valid } \\
\text { Valid } \\
\text { Valid } \\
\text { Valid } \\
\text { Valid }\end{array}$ \\
\hline $\mathrm{Y}$ & $\begin{array}{c}\text { Y.1 } \\
\text { Y.2 } \\
\text { Y.3 } \\
\text { Y.4 } \\
\text { Y.5 } \\
\text { Y.6 } \\
\text { Y.7 } \\
\text { Y.8 } \\
\text { Y.9 } \\
\text { Y.10 }\end{array}$ & $\begin{array}{l}1.00 \\
1.00 \\
0.85 \\
0.85 \\
1.00 \\
1.00 \\
1.00 \\
1.00 \\
0.96 \\
0.96\end{array}$ & $\begin{array}{c}39.74 \\
39.74 \\
5.89 \\
34.03 \\
39.74 \\
39.74 \\
39.74 \\
39.74 \\
12.35 \\
12.35\end{array}$ & $\begin{array}{l}1.77 \\
1.77 \\
1.77 \\
1.77 \\
1.77 \\
1.77 \\
1.77 \\
1.77 \\
1.77 \\
1.77\end{array}$ & $\begin{array}{l}0.05 \\
0.05 \\
0.05 \\
0.05 \\
0.05 \\
0.05 \\
0.05 \\
0.05 \\
0.05 \\
0.05\end{array}$ & $\begin{array}{l}\text { Valid } \\
\text { Valid } \\
\text { Valid } \\
\text { Valid } \\
\text { Valid } \\
\text { Valid } \\
\text { Valid } \\
\text { Valid } \\
\text { Valid } \\
\text { Valid }\end{array}$ \\
\hline
\end{tabular}


Pada pengujian validitas menggunakan dua variabel yaitu variabel $X$ dan juga variabel $Y$ dengan jumlah item pertanyaan setiap variabel berjumlah 10 item pertanyaan sehingga menimbulkan nilai korelasi yang berbeda-beda dan begitu juga dengan nilai t hitung yang mempunyai nilai yang berbeda-beda untuk setiap itemnya tetapi mempunyai signifikan yang valid karena menggunakan signifikan pada pengujian validitas adalah 0.05 atau 5\%. untuk t tabel setiap itemnya sama. Korelasi $\mathrm{t}$ hitung menunjukkan korelasi yang signifikan jika $\mathrm{t}$ tabel $<\mathrm{t}$ hitung dinyatakan valid untuk tingkat kepercayaan $95 \%$.

Pengujian validitas ini menunjukkan bahwa adanya keterkaitan antar variabel yang dinyatakan dalam keterangan valid setiap item yang berasal dari kedua variabel. Hasil tersebut nantinya dijadikan sebagai acuan untuk pengujian berikutnya untuk mengetahui konsistensi dan signifikan kedua variabel yang akan dibuktikan dengan sebuah nilai yang berasal dari perhitungan pengujian tersebut.

\section{2 pengujian Reliabilitas}

Pengujian dilakukan untuk mencari tahu konsistensi dari alat ukur. Dapat dikatakan bahwa alat ukur mempunyai nilai yang konsisten jika pengukurannya dilakukan berulang kali.

Pengujian dilakukan dengan menganalisis semua item pertanyaan yang ada menggunakan alpha cronbach. Pengujian bernilai konsisten (reliabel) apabila alpha cronbach > 0.6. Berikut hasil pengujian reliabilitas yaitu :

Tabel 3. Pengujian Reliabilitas

\begin{tabular}{|c|c|c|}
\hline Variabel & $\begin{array}{c}\text { Alpha } \\
\text { Cronbach }\end{array}$ & Keterangan \\
\hline $\begin{array}{c}\text { Variabel X } \\
\text { Lingkungan Kerja }\end{array}$ & 0,98 & Reliabel \\
\hline $\begin{array}{c}\text { Variabel Y } \\
\text { Kinerja Pegawai }\end{array}$ & 0,99 & Reliabel \\
\hline
\end{tabular}

Berdasarkan pada tabel 3, disimpulkan bahwa nilai alpha cronbach dari variabel $\mathrm{X}$ dan variabel dari 0.6 dinyatakan reliabel serta dapat diterima dikarenakan mempunyai nilai alpha cronbach variabel X sejumlah 0,98 sedangkan nilai alpha cronbach variabel Y sejumlah 0,99.

\subsection{Analisis Regresi Sederhana}

Regresi Sedehana ini dilakukan sebagai pembuktian hipotesis mengenai variabel $\mathrm{X}$ dan variabel Y. Berikut hasil analisis regresi sederhana yaitu :

Tabel 4. Uji Analisis Sederhana

\begin{tabular}{|l|c|c|c|c|}
\hline \multicolumn{1}{|c|}{ Model } & Coefficients & $\begin{array}{c}\text { Standard } \\
\text { Error }\end{array}$ & $\mathbf{t}$ & Sig. \\
\hline Intercept & -4.64 & 1.74 & -2.67 & 0.02 \\
\hline $\mathrm{X}$ & 1.10 & 0.04 & 26.38 & 0.00 \\
\hline
\end{tabular}

Persamaan regresi sederhana dapat dijelaskan dengan :

$$
\begin{gathered}
Y=\alpha+\beta X+e \\
Y=-4.64+1.10 X
\end{gathered}
$$

Penjelasan persamaan regresi sederhana yaitu :

a. $\quad \boldsymbol{\alpha}=$ nilai koefisien sebesar -4.64 artinya bila variabel $\mathrm{X}$ nilainya 0 , sehingga variabel Y nilainya menjadi negatif yaitu sebesar -4.64 .

b. $\boldsymbol{\beta}=1.10$ berarti apabila kinerja pegawai nambah 1 poin, sehingga nilai kinerja pegawai naik sejumlah 1.10 . Koefisien itu bernilai positif berarti terdapatnya pengaruh positif terhadap kedua variabel tersebut. 


\subsection{Analisis Korelasi $(R)$}

Korelasi ini untuk menunjukkan ikatan linear terhadap dua variabel yang dinyatakan dalam nilai korelasi. Berikut adalah hasil dari analisis korelasi (R) :

Tabel 5. Analisis Korelasi (R)

\begin{tabular}{|c|c|c|c|c|}
\hline Observations & Multiple R & $\begin{array}{c}\text { R } \\
\text { Square }\end{array}$ & $\begin{array}{c}\text { Adjusted } \\
\text { R Square }\end{array}$ & $\begin{array}{c}\text { Standard } \\
\text { Error }\end{array}$ \\
\hline 15 & 0.99 & 0.98 & 0.98 & 0.96 \\
\hline
\end{tabular}

Berdasarkan pada tabel 5, dapat dilihat bahwa dari 15 item dengan multiple $R$ sebesar 0.99 dan mempunyai standard error sebesar 0.96, bisa disimpulkan kalau terdapatnya ikatan positif yang besar antara variabel X (Lingkungan kerja) dengan variabel Y (Kinerja Pegawai).

\subsection{Pengujian Hipotesis (Uji t)}

Pengujian hipotesis yang dipakai untuk mengenali pengaruh antar variabel yaitu variabel $\mathrm{X}$ (Lingkungan Kerja) dengan variabel Y (Kinerja Pegawai).

a. Apabila nilai sig uji $\mathrm{t}<0.05$, dinyatakan Ho ditolak maksudnya menunjukkan pengaruh secara signifikan antara kedua variabel.

b. Apabila nilai sig uji $t>0.05$, dinyatakan Ho diterima maksudnya tidak menunjukkan pengaruh secara signifikan antara kedua variabel.

Tabel 6. Uji Hipotesis (Uji t)

\begin{tabular}{|l|c|c|c|c|}
\hline \multicolumn{1}{|c|}{ Model } & Coefficients & $\begin{array}{c}\text { Standard } \\
\text { Error }\end{array}$ & $\mathbf{t}$ & Sig. \\
\hline Intercept & -4.64 & 1.74 & -2.67 & 0.02 \\
\hline $\mathrm{X}$ & 1.10 & 0.04 & 26.38 & 0.00 \\
\hline
\end{tabular}

Bersumber pada tabel 6, nilai uji t dengan variabel $\mathrm{X}$ (Lingkungan Kerja) mendapat nilai koefisien sebesar 1.10, SE sebesar 0.04 dan nilai t sebesar 26.38, nilai signifikan 0.00 dengan alpha 0.05 dikarenakan nilai signifikan $\mathrm{t}$ jauh lebih kecil dibandingkan alpha $(0.00<0.05)$, hingga disimpulkan Ho ditolak maksudnya variabel $X$ (Lingkungan Kerja) menunjukkan pengaruh signifikan dengan variabel Y (Kinerja Pegawai).

\section{Kesimpulan}

Berdasarkan dari permasalahan yang dibahas, didapat sebuat kesimpulan yaitu :

a. Penelitian ini menggunakan metode kuantitatif karena diperlukan adanya pengujian-pengujian yang membuktikan bahwa adanya pengaruh antar varibel. Dengan perasional variabel yaitu menggunakan skala pengukuran yaitu skala ordinal karena untuk membedakan data melalui penilaian tertentu seperti pengujian-pengujian yang berhubungan dengan metode yang digunakan pada penelitian ini. Dalam melakukan pengujian-pengujian peneliti mengunakan 15 sampel yang berasal dari selutruh jumlah pegawai Kelurahan Salembaran Jaya.

b. Uji Validitas ini menggunakan korelasi $r$ hitung yaitu korelasi t hitung menunjukkan korelasi yang signifikan jika $t$ tabel $<\mathrm{t}$ hitung dinyatakan valid untuk tingkat kepercayaan $95 \%$. Apabila $\mathrm{t}$ tabel $<\mathrm{t}$ hitung dinyatakan valid sedangkan $\mathrm{t}$ hitung $<\mathrm{t}$ tabel dinyatakan tidak valid.

c. Uji Reliabilitas menyimpulkan bahwa bahwa nilai alpha cronbach dari variabel $\mathrm{X}$ dan variabel dari 0.6 dinyatakan reliabel serta dapat diterima dikarenakan mempunyai nilai alpha cronbach variabel X sejumlah 0,98 dan nilai alpha cronbach variabel Y sejumlah 0,99.

d. Uji Regresi Linier Sederhana yaitu $\mathrm{Y}=-4.64+1.10 \mathrm{X}$ artinya terdapatnya pengaruh positif terhadap kedua variabel tersebut. 
e. Pada analisis korelasi (R) menyatakan bahwa dari 15 item dengan nilai korelasi sebesar 0.99, hingga bisa disimpulkan kalau terdapatnya ikatan positif yang besar antara variabel $\mathrm{X}($ Lingkungan kerja) dengan variabel Y Kinerja Pegawai).

f. Uji Hipotesis (Uji t) menyimpulkan bahwa nilai uji t dengan variabel X (Lingkungan Kerja) mendapat nilai koefisien sebesar 1.10, SE sebesar 0.04 dan nilai t sebesar 26.38, nilai signifikan 0.00 dengan alpha 0.05 dikarenakan nilai signifikan t jauh lebih kecil dibandingkan alpha $(0.00<0.05)$, hingga disimpulkan Ho ditolak maksudnya variabel $\mathrm{X}$ (Lingkungan Kerja) menunjukkan pengaruh signifikan dengan variabel Y (Kinerja Pegawai).

\section{Saran}

Dari permasalahan serta pembahasan yang sudah diterangkan sebeumnya peneliti memberikan bebera saran agar menjadi bahan acuan untuk penelitian berikutnya. Berikut beberapa saran yang peneliti dapat berikan yaitu :

a. Memperbaiki lingkungan kerja pegawai terutama pada ruang gerak antar pegawai serta jarak antar pegawai, sehingga pegawai dapat leluasa dalam melaksanakan pekerjaannya dan dapat mematuhi protokol covid-19 yang salah satunya yaitu menjaga jarak satu sama lain.

b. Lebih meningkatkan kesadaran diri sendiri yaitu para pegawai Kelurahan Salembaran Jaya untuk melakukan pencegahan penularan covid-19 serta mengingatkan satu sama lain untuk mematuhi protokol yang telah diterapkan.

c. Menjalin komunikasi yang baik dengan atasan, sesama pegawai dan terutama kepada masyarakat yang mempunyai kepentingan pada Kelurahan Salembaran Jaya agar mendapat nilai positif dari masyarakat.

d. Adanya penelitian lanjutan dengan pembahasan yang sama dan lokasi yang sama untuk menyempurnakan penelitian dikemudian hari.

\section{DAFTAR PUSTAKA}

[1]. Apriliawati, D. (2020). Diary Studi Sebagai Metode Pengumpulan Data pada Riset Kuantitatif: Sebuah Literature Review. Journal of Psychological Perspective, 2(2), 79-89.

[2]. Auliya, M. (2021). Persepsi Dan Sikap Masyarakat Kelurahan Sungai Dama Terhadap Peraturan Daerah (Perda) Kota Samarinda Nomor 02 Tahun 2011 Tentang Pengelolaan Sampah Dan Pelaksanaanny. eJournal Sosiatri-Sosiologi, 9(1), 65-77.

[3]. Darwin, K. (2020). Analisis Dimensi Sumber Daya Manusia Dalam Mendukung Kinerja Organisasi. Jurnal Ilmu Ekonomi, 3(2), 181-190.

[4]. Harahap, S. F., \& Tirtayasa, S. (2020). Pengaruh Motivasi, Disiplin dan Kepuasan kerja terhadap Kinerja Karyawan Pada PT. angkasa Pura II (Persero) kantor Cabang Kualanamu. Jurnal Ilmiah Magister manajemen, 3(1), 120-135.

[5]. Herdani, G., Suwarsi, S., \& Harahap, D. A. (2021). Pengaruh Motivasi Kerja dan Konflik Kerja terhadap Kinerja Karyawan pada Masa Pandemi COVID-19. Prosiding Manajemen, 7(1), 16-20.

[6]. Hizbullah, M., \& Haidir. (2021). pengaruh Kepemimpinan Tehadap Disiplin Kerja Pegawai Pada Kantor Dinas Pendidikan. Jurnal Ilmiah Metadata, 3(1), 331-343.

[7]. Kamil, M., Septiawan, T., \& Taharuddin. (2020). Pengaruh Pemberian Terapi Elektroakupuntur terhadap Nilai Tekanan Darah pada Pasien Hipertensi: Literature Review. Borneo Student Research , 2(1), 235-240. 
[8]. Nabawi, R. (2019). Pengaruh Lingkungan Kerja, Kepuasan kerja dan Beban kerja Terhadap kinerja Pegawai. Jurnal Ilmiah Magister Manajemen, 2(2), 170-183.

[9]. Nurjaya, Sunarsi, D., Effendy, A. A., Teriyan, A., \& Gunartim. (2021). Pengaruh Etos Kerja Dan Disiplin Kerja Terhadap Kinerja Pegawai Pada Dinas kehutanan Dan Perkebunan Kota Bogor. Jurnal Ilmiah, Manajemen Sumber Daya Manusia, 4(2), 172-184.

[10]. Purwanto, A., Purba, J. T., Bernarto, I., \& Sijabat, R. (2021). Pengaruh Servant, Digital dan Green Leadership terhadap Kinerja Industri Manufaktur melalui Mediasa Komitmen Organisasi. Jurnal Riset Inspirasi Manajemen dan Kewirausahaan, 5(1), 1-13.

[11]. Purwanto, A., Asbari, M., Santoso, P., Wijayanti, L., Hyun, C., sihite, O., \& Saifuddin, M. (2020). Pengaruh Gaya Kepemimpinan Partisipatif dan Otokratis Terhadap Kinerja Sistem Jaminan Halal HAS 23000 Pada Industri Makanan Kemasan. Edumaspul: Jurnal Pendidikan, 4(1), 156-179.

[12]. Rahmawati, N. P., Swasto, B., \& Prasetya, A. (2014). PENGARUH LINGKUNGAN KERJA TERHADAP KINERJA PEGAWAI (Studi Pada Karyawan Kantor Pelayanan Pajak Pratama Malang Utara). Jurnal Ilmiah Magister Manajemen, 4(1), 1-9.

[13]. Rivai, A. (2021). Pengaruh Pengawasan, Disiplin dan Motivasi Terhadap Kinerja Guru. Jurnal Administrasi Bisnis (JAB), 8(2), 11-22.

[14]. Rulianti, E., Nurpribadi, G., \& Amirudin, R. (2021). Peran Motivasi dalam Memediasi Pengaruh Lingkungan Kerja terhadap Kinerja Karyawan. Jurnal Ekonomi \& Ekonomi Syariah (JESYA), 4(2), 963-973.

[15]. Sarwani, Akbar, I. R., Handoko, A. L., Ilham, D., \& Wijoyo, H. (2020). Pengaruh Pelatihan dan Motivasi terhadap Produktivitas Kerja Karyawan pada PT. Lion Mentari Airlines Bandara Internasional Soekarno Hatta Cengkareng. Jurnal Ilmu Komputer dan Bisnis (JIKB), 11(2), 91100.

[16]. Soyan, D. K. (2013). Pengaruh Lingkungan Kerja Terhadap Kinerja Kerja Pegawai BAPPEDA. Malikussaleh Industrial Engineering Journal, 2(1), 18-23.

[17]. Sujono, \& Suhada, B. (2021). Pengaruh Lingkungan Kerja dan produktivitas Kerja Terhadap Kinerja Pegawai Rumah Sakit Umum daerah A. Yani Kota Metro Di Masa Pandemi Covid-19. Jurnal Manajemen Diversivikasi, 1(3), 537-543.

[18]. Sulistiawati, R. (2012). Pengaruh Upah Minimum terhadap Penyerapan Tenaga Kerja dan Kesejahteraan Masyarakat di Provinsi di Indonesia. Jurnal EKsos, 8(3), 195-211.

[19]. Sunarsi, D. (2020). Pengaruh Lingkungan Kerja Terhadap Kinerja Karyawan Pada PT. Mentari Persada di Jakarta. Seminar Nasional Manajemen, Ekonomi dan Akuntasi Fakultas Ekonomi dan Bisnis UNP Kediri, 117-123. 